Canadian Journal of Applied Linguistics

Revue canadienne de linguistique appliquée

\title{
Exploring Trends in 21st Century Canadian K-12 French as Second Language Research: A Research Synthesis
}

\section{Stephanie Arnott, Mimi Masson and Sharon Lapkin}

Volume 22, Number 1, 2019

Special Issue: In Memory of Larry Vandergrift

Numéro spécial : à la mémoire de Larry Vandergrift

URI: https://id.erudit.org/iderudit/1060906ar

DOI: https://doi.org/10.7202/1060906ar

See table of contents

Publisher(s)

University of New Brunswick

ISSN

1920-1818 (digital)

Explore this journal

Cite this article

Arnott, S., Masson, M. \& Lapkin, S. (2019). Exploring Trends in 21st Century Canadian K-12 French as Second Language Research: A Research Synthesis. Canadian Journal of Applied Linguistics / Revue canadienne de linguistique appliquée, 22(1). https://doi.org/10.7202/1060906ar

\section{Article abstract}

This research synthesis aims to investigate the broader trends in K-12 French as a second language (FSL) published research from 2000-2017 (inclusive). We assembled a database of 181 peer-reviewed articles relating to FSL education to examine what we already know about specific issues. We used Nvivo 11 (Pro) to facilitate coding the articles for key words and findings (among other codes). Four prevalent research topics emerged in terms of frequency of occurrence: literacy, French language form, French language instruction, and student background. In this article, after exploring each issue by synthesizing main findings, we summarize what we know and what remains to be discovered about each topic. We conclude by suggesting relevant directions for future research, such as focusing on programs other than French immersion and working with First Nations, Métis, and Inuit communities to better understand FSL learning in these contexts.
Copyright (c) Stephanie Arnott, Mimi Masson, Sharon Lapkin, 2019

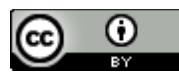

This document is protected by copyright law. Use of the services of Érudit (including reproduction) is subject to its terms and conditions, which can be viewed online.

https://apropos.erudit.org/en/users/policy-on-use/ 


\title{
Exploring Trends in $21^{\text {st }}$ Century Canadian K-12 French as a Second Language Research: A Research Synthesis
}

\author{
Stephanie Arnott \\ University of Ottawa \\ Mimi Masson \\ University of Ottawa \\ Sharon Lapkin \\ Ontario Institute for Studies in Education (OISE), University of Toronto
}

\begin{abstract}
This research synthesis aims to investigate the broader trends in K-12 French as a second language (FSL) published research from 2000-2017 (inclusive). We assembled a database of 181 peer-reviewed articles relating to FSL education to examine what we already know about specific issues. We used Nvivo 11 (Pro) to facilitate coding the articles for key words and findings (among other codes). Four prevalent research topics emerged in terms of frequency of occurrence: literacy, French language form, French language instruction, and student background. In this article, after exploring each issue by synthesizing main findings, we summarize what we know and what remains to be discovered about each topic. We conclude by suggesting relevant directions for future research, such as focusing on programs other than French immersion and working with First Nations, Métis, and Inuit communities to better understand FSL learning in these contexts.
\end{abstract}

\section{Résumé}

Cette synthèse de recherche vise à faire une enquête des tendances générales de la recherche publiée dans le domaine du français langue seconde (FLS) de la maternelle à la $12^{\mathrm{e}}$ année entre 2000-2017 (inclusif). Notre base de données de 181 articles évalués par les pairs dans le domaine du FLS nous a permis d'extraire ce qu'on sait dans certains domaines spécifiques. Nous avons utilisé le programme Nvivo 11 (Pro) pour coder et analyser les mots-clés et les résultats (entre autres) de chaque article. Quatre thèmes en sont ressortis en termes de fréquence : la littératie, les formes de la langue française, la didactique du FLS et les caractéristiques des apprenants. Dans cet article, nous discutons de chaque thème en synthétisant les résultats principaux ; ensuite, nous résumons ce que nous savons et ce qui reste à découvrir dans chaque domaine. En conclusion, nous offrons des pistes possibles pour les recherches à venir, telles que le besoin d'accroitre le nombre d'études effectuées dans les programmes de FLS autres que l'immersion française et le besoin de travailler davantage avec les communautés des Premières Nations, Métis et Inuits pour mieux comprendre l'apprentissage du FLS dans ces contextes. 


\section{Exploring Trends in $21^{\text {st }}$ Century Canadian K-12 French as Second Language Research: A Research Synthesis}

\section{Introduction}

In 2015, the Canadian Standing Senate Committee on Official Languages conducted a study on best practices for language policies and second language (L2) learning in Canada. The committee identified research as a priority area for promoting and sharing good practices and for highlighting what makes for successful L2 programming. With regard to French as a second language (FSL) in particular, the study made an explicit call for more widespread dissemination of the latest research results in this area of official language programming.

Since the turn of the century, numerous research articles and reports focusing on different aspects of Kindergarten to Grade 12 (K-12) FSL programming in Canada have synthesized findings from existing studies (e.g., Carr, 2009; Genesee, 2007; Lapkin, MacFarlane, \& Vandergrift, 2006; Lapkin, Mady, \& Arnott, 2009; Lazaruk, 2007; Mady, 2007). While these analyses represent rich examinations of relevant topics, a comprehensive investigation of the broader trends in K-12 FSL published research has yet to be undertaken. As experienced scholars in the area of research syntheses advocate (e.g., H. M. Cooper, Patall, \& Lindsay, 2013; L. Cooper \& Hedges, 2009; Norris \& Ortega, 2006), conducting a research synthesis enables stakeholders to examine what is already known about a specific issue, to ascertain how it has been addressed methodologically, and to determine where we need to go next with our research.

With this in mind, we endeavour to provide a systematic synthesis of the empirical research studies published between 2000 and 2017 (inclusive) that focus on K-12 FSL teaching and learning across Canada. We begin this task by outlining explicitly how the relevant literature was searched and how primary studies were selected for inclusion in our database and subsequent analysis. Then, we present findings from our qualitative analysis of the database using NVivo to ascertain what issues are top of mind in FSL research. Essentially, this research synthesis aims to collate findings and examine particular categories of data that "cut across studies, in order to create as systematic a depiction as possible about what we know, what we do not know, and why" (Norris \& Ortega, 2006, p. 6). We conclude the article by outlining points of reference for interpreting both existing and future research in the area of K-12 FSL education, along with suggestions for areas that would benefit from more empirical attention.

\section{Methodology}

The procedures followed for this research synthesis are outlined below, starting with decisions on studies to include/exclude and moving on to procedures for collecting and analyzing the articles. Generally speaking, a critical interpretive synthesis approach (DixonWoods et al., 2005; Flemming, 2010) was used to represent the diverse and complex nature of FSL research in our database. In this approach, a strong rationale and method are offered for analyzing findings generated through different research epistemologies (i.e., qualitative and quantitative research). We took inspiration from Glaser and Strauss (1967), who demonstrated how quantitative data can be used when building theory to develop a qualitative synthetic approach. This was particularly useful for building new lines of 
understanding when synthesizing the research. As Barbour (1998) argued, the approach that qualitative researchers use to examine contradictions and tensions within the same conceptual and methodological handling could also be applied to synthesize evidence produced by different methods. Inherent to this method was infusing a critical component to ensure approaches, perspectives, limitations, and contradictions were taken into consideration when synthesizing the data.

\section{Inclusion Criteria}

Our criteria for entering articles into the database were: empirical studies published between 2000 and 2017 (inclusive) in peer-reviewed journals treating data first-hand (e.g., applying new or unique analysis) on the topic of FSL programs (e.g., core French [CF], extended French [EF], French immersion [FI] and intensive French [IF]) in Canadian schooling contexts from K-12. ${ }^{1}$ We also included articles on FSL teacher education - that is, articles that dealt with preservice teachers or programs preparing teacher candidates to work in K-12 contexts in Canada and/or studies pertaining to continuous learning and professional development for in-service teachers. Works from qualitative, quantitative, and mixed methods orientations were included. We gathered English-language and Frenchlanguage articles alike. However, studies were limited to those situated in English-language schools; consequently, studies conducted within French-language school boards were excluded. We chose to focus on journal articles to limit our scope to a manageable database. Therefore, we excluded position papers, papers detailing potential pedagogical approaches, reports commissioned by associations (e.g., Canadian Association of Second Language Teachers, Canadian Parents for French, Ontario Modern Language Teachers' Association), books, book chapters, and doctoral theses. We also chose to work with peerreviewed journals to ensure the standardized quality, and accessibility and format of the articles in our database.

\section{Procedure}

Our research team ran searches for articles in several waves. First, we selected four major journals we judged would contain articles relevant to the FSL context in Canada: Modern Language Journal, Canadian Journal of Applied Linguistics, Canadian Modern Language Review, International Journal of Bilingual Education. Then, we used the references in the articles we found to look for other articles, which extended our search to other journal publications. We then used the search engines ProQuest, PsychInfo, ERIC, Education Source and Google Scholar to broaden our search. Using the search terms "French as a Second Language" + "Canada"/"FSL" + "Canada"/“Français langue seconde" + "Canada"/“FLS" + "Canada" helped to extend the scope of journal publications from which we were drawing. The resulting database contains 61 different journals, with the top four being Canadian Modern Language Review, Canadian Journal of Applied Linguistics, Canadian Journal of Education, and International Journal of Bilingual Education.

Before finalizing our database, we contacted all first authors in our list to ask for confirmation that we had found all relevant articles they had published or were aware of that focused on K-12 FSL education in Canada and were published between 2000 and 2017 inclusive. We also contacted editors of journal publications in which we had found at least two articles, for confirmation that their latest publications were available online. Both 
groups suggested additional articles and authors to add to the list. The resulting database contains a total of 181 articles.

A PDF version of each article was downloaded into Nvivo 11 (Pro) for coding. Table 1 summarizes all the aspects of the articles that were coded. Articles were coded for bibliographic information, such as Author, Year of publication, Journal, and Language of publication. We also coded the articles for content information, that is Methodology, Panel, Stakeholder, and Programs. While the focus was usually on a set group of people, studies coded as "policy" dealt with document analysis of policy documents. In some cases, studies were coded as more than one of the content information codes, depending on the study design. For instance, some studies took place across several programs, or several panels. We then coded the study design for each article: Key words, Theoretical framework, Study type, Setting, Data collection, Data analysis, and Findings. For the purpose of this article, we will focus on the Key words coding that emerged. To ascertain what issues are top of mind, we extracted all Key words listed in each article. When Key words were not provided by the author(s), we generated them ourselves based on a thematic analysis of the articles. In many cases, articles had more than one key word, meaning the same article could be coded as part of several top-of-mind issues. We synthesized both the most frequently occurring Key words in the database, and the Findings reported connected to each Key word. Said differently, this analysis facilitated a discussion on what researchers have been focusing on and what they have found in K-12 FSL research published between 2000 and 2017. The list and frequency of key words coded can be found in Appendix A.

It is important to note that coding was not exclusive. Some studies were coded as more than one item when it came to the Key words, Panel, the Stakeholder or the Program, depending on the design of the study. These closed- and open-coding categories enabled us to run cross-sectional analysis within and across different groups of studies for closer anlaysis (Duff, Norris, \& Ortega, 2007).

Inter-rater reliability tests were also conducted to ensure that different members of the research team were coding the findings in the same way. For this, three members of the research team coded findings from 11 randomly selected articles (at the time, our database consisted of 97 articles and this made up roughly $10 \%$ of our database). The analysis confirmed that we were in agreement on this coding $96 \%$ of the time. 
Table 1

Codebook for Studies in the Database

\begin{tabular}{ll}
\hline Code & Definition \\
\hline Bibliographic Information & \\
\hline $\begin{array}{l}\text { Author(s) } \\
\text { Jear }\end{array}$ & $\begin{array}{l}\text { Author's last name(s) } \\
\text { Year of publication } \\
\text { Language }\end{array}$ \\
\hline Journal of publication \\
English or French language of publication
\end{tabular}

\section{Limitations}

The fact that scholarly work in the form of book chapters, research reports, policy documents, theses, et cetera were omitted from the scope of this article constitutes a limitation of our study; however, limiting the scope of the database in this way was necessary to keep the project manageable. While we assumed that the peer-review process offered a sufficient measure of trustworthiness and research quality, we were also required to make critical judgements on the quality of the research gathered (H. M. Cooper et al., 2013). In many cases, we were forced to infer key details of studies where explicit references were missing, resulting in alternate codes being created and applied during our analysis. For example, although it may have been clear that data were collected in Canada, some studies did not explicitly report where the study was conducted (in such instances, the articles were coded as "location not reported"). Other studies lacked conceptual or methodological clarity as to how the data were collected and treated for analysis. For articles in which the conceptual framework could not be identified (as was the case with nine studies), we coded them as "conceptual framework not stated." Although some methodological processes were described in more detail in some articles than in others, we were able to gather the basic methodological information in all of the studies, including data collection procedures (e.g., interviews, tests) and method of analysis (e.g., content analysis, inferential statistics). The most limiting barrier to completing this research 
synthesis was studies that did not provide clear findings that could easily be identified and extracted. In some cases, findings seemed to blur into implications for the field. In these instances, we made special efforts to review the articles' research questions and identify the results that responded to these questions. It must be noted that only a very small segment of the studies in the database presented these issues. Despite these limitations, we were able to retain a total of 181 studies pertaining to the Canadian K-12 FSL context to provide an overall snapshot of the content and quality of research conducted in the field.

\section{Findings}

In this section, we present relevant findings from our analysis of the database in an effort to ascertain what we know about Canadian K-12 FSL education. We begin by presenting the four most prevalent issues that are top-of-mind (implicating 113 of the 181 articles in the database) and synthesizing the findings from relevant research related to each issue. As Table 2 shows, our synthesis of key words revealed that the four issues that were most prevalent in the database of articles were (in order of frequency from highest to lowest): (a) literacy; (b) French language form (FLF); (c) French language instruction (FLI); and (d) student background (SB). Sample key words that were organized under each of the four topic categories are included, as well as the total number of articles where these key words appeared. The full list of key words is available in Appendix A. The distribution of the four issues across different FSL programs is also presented, showing an overall dominance of FSL research focusing on the FI program, with particular interest in topics such as literacy and FLF in this context.

Table 2

Top Four Issues and Distribution Across French as a Second Language (FSL) Programs

\begin{tabular}{|c|c|c|c|c|c|c|c|}
\hline Rank & Issue & Sample Key Words Coded & $\mathrm{CF}$ & FI & $\mathrm{EF}$ & IF & $\begin{array}{l}\text { Total \# of } \\
\text { articles }^{\text {a }}\end{array}$ \\
\hline 1 & Literacy & $\begin{array}{c}\text { reading, writing, biliteracy, } \\
\text { phonemic awareness, } \\
\text { multiliteracies }\end{array}$ & 5 & 42 & 1 & 1 & 47 \\
\hline 2 & $\begin{array}{l}\text { French } \\
\text { language } \\
\text { form }\end{array}$ & $\begin{array}{c}\text { grammar, phonological } \\
\text { awareness, reformulation, } \\
\text { metalinguistics }\end{array}$ & 7 & 33 & 1 & 2 & 39 \\
\hline 3 & $\begin{array}{l}\text { French } \\
\text { language } \\
\text { instruction }\end{array}$ & $\begin{array}{l}\text { pedagogy, teaching } \\
\text { strategies, effective } \\
\text { practice, FSL teaching } \\
\text { methodology }\end{array}$ & 19 & 20 & 1 & 2 & 37 \\
\hline 4 & $\begin{array}{c}\text { Student } \\
\text { background }\end{array}$ & $\begin{array}{l}\text { immigration, allophones, } \\
\text { gender, citizenship }\end{array}$ & 10 & 17 & 1 & 4 & 30 \\
\hline
\end{tabular}

Note. $\mathrm{CF}=$ core French; FI = French immersion; EF = extended French; IF = intensive French.

a Some articles may address more than one program (i.e., CF, FI, EF, IF). 
Interestingly, the issues that were top of mind varied slightly by program. The top four issues for FI were literacy, FLF, FLI, and professional development. In FI, SB was still an important topic as it ranked among the top five. However, FI research has also focused to a greater extent than other programs on teacher professional development. In particular, these studies examined different approaches to teacher professional learning (see Masson, Arnott, \& Lapkin, 2018). The top four issues for CF were FLI, professional development, $\mathrm{SB}$, and motivation. This last issue (i.e., motivation), which is more top-of-mind in the CF context than in FI, reminds us that one of the pervasive issues for $\mathrm{CF}$ is maintaining motivation among students who are studying a mandatory subject (Arnott, in press; Desgroseilliers, 2012, 2017). The dynamics of this means teachers' focus and students' attention must be maintained through alternate means that are rarely, if ever, discussed in studies set in FI contexts. That FI studies make up 66\% $(n=120)$ of all studies in this database suggests that motivation is an under-studied area of research in the FSL literature. For EF $(n=8)$, the top four key words are the Common European Framework for Reference (CEFR), inclusion, professional development, French language learning. In IF $(n=13)$, the top four key words are made up of inclusion, SB, exceptionalities, and FLI. In this case, it seems research in IF tackles issues pertaining to the different kinds of students in the program, within the context of approaching teaching differently in the IF classroom (e.g., Collins, Stead, \& Woolfrey, 2004). However, since these last two programs make up such a small proportion of studies in the entire database (i.e., $4 \%$ and $7 \%$ respectively), it is difficult to acertain trends.

Further analysis of the key words as they appeared across the 2000-2017 timespan reveals an overall upward trend in the quantity of studies being published on K-12 FSL education (see Figure 1). Looking at the top four key words, a consistent research focus was maintained on some issues (e.g., literacy, FLI, and FLF) throughout the years, while in some time periods there were noticeable increases in research focusing on SB (2007-2016).

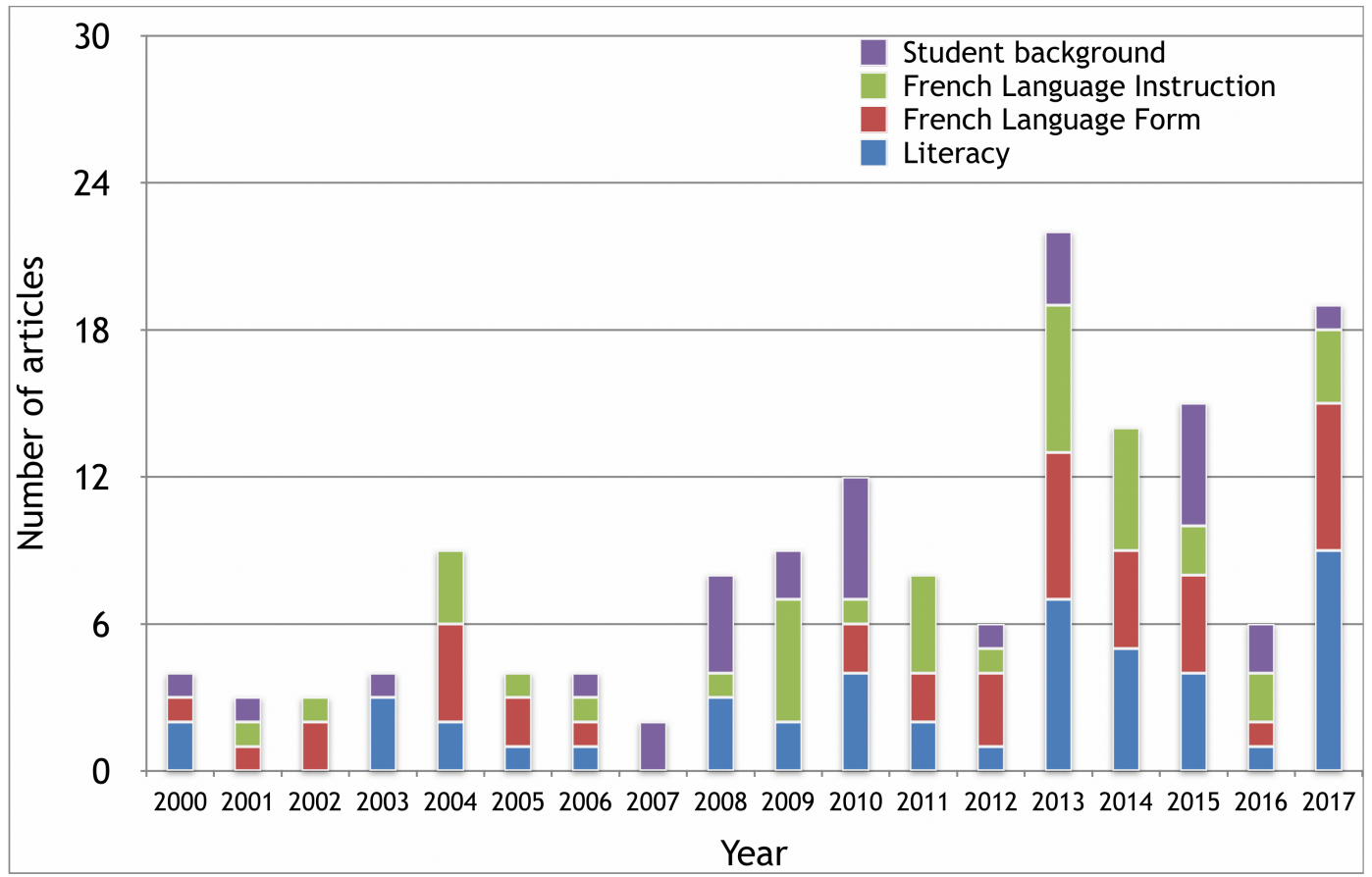

Figure 1. Distribution of top four key words from 2000 to 2017. 
In the sections that follow, findings from studies linked to each topic are synthesized in order to provide a glimpse into what the research has to say in relation to each of these relevant issues. Select examples are provided in an effort to illustrate each topic generally, as well as the diversity of themes that emerged from our analysis of the findings from studies grouped under each topic. The resulting synthesis provides a look at the variety of perspectives taken on researching each topic, and the resulting insights gained from such analysis.

\section{Literacy}

Articles focusing on the development of FSL literacy skills have concentrated predominantly on the FI context $(88 \%)$, as well as traditional conceptualizations of literacy (i.e., reading and writing skills, phonemic awareness). Other publications delve further into reconceptualizations of literacy to include cross-linguistic transfer and digital storytelling. In general, findings from these studies identify specific factors that appear to influence FI students' reading and writing skills, as well as interventions showing significant potential for improving their French literacy skill development.

Studies focusing on traditional literacy skill development in French have revealed the potential for different factors to significantly impact students' reading and writing competencies. For example, factors identified as predicting FSL reading skill development include early literacy skills (Bourgoin, 2014); phonological awareness and orthographic processing (Chung, Koh, Deacon, \& Chen, 2017); oral language skills (Hipfner-Boucher, Lam, \& Chen, 2015); and age of exposure to multiple languages (Bérubé \& MarinovaTodd, 2014; Jasińska \& Petitto, 2017). School-based language learning experiences (Saindon, Landry, \& Boutouchent, 2011) and vocabulary richness and grammatical accuracy (Knouzi \& Mady, 2017) have also been identified as affecting FSL students' quality of writing. In the majority of cases, these factors were measured and compared across students' first language (L1, commonly English) and L2 (French), often demonstrating the predictive potential of competency in the L1 to predict competency in the L2 (and in some cases, vice-versa).

Noteworthy work has also been done to identify factors predicting the reading and writing abilities of at-risk readers in FI, as well as specific interventions showing the potential to help struggling French readers and writers to improve. For example, Jared, Cormier, Levy, and Wade-Wooley (2010) identified specific L1 measures (e.g., English receptive vocabulary) that predicted potential reading difficulty in the L2 (French). Le Bouthillier (2015) detailed the positive impact of explicit teacher modeling on struggling French writers in the FI context. Research by Wise and Chen $(2010,2015)$ has also shown that phonological awareness instruction given in English to at-risk readers in early FI students can significantly improve their reading skills. Subsequent research suggested that gains experienced immediately following this specific intervention were maintained for two years (see Wise, D'Angelo, \& Chen, 2016). Other relevant studies have detailed the literacy skill development of at-risk readers (Kruk \& Reynolds, 2012) as well as their perspectives on their experiences in FI (Capina \& Bryan, 2017).

Additional articles have documented the impact of specific interventions targeting literacy-based instruction (e.g., Cormier \& Turnbull, 2009; Germain, Netten, \& Séguin, 2004); peer tutoring (Bournot-Trites, Lee, \& Séror, 2003); and digital storytelling (Priego 
\& Liaw, 2017) on the development of students' literacy skills, with all showing positive results in this regard. Several studies have also reported on interventions involving the use of bilingual books with French learners in schools, detailing teachers' practices during the implementation of these interventions and providing evidence for the positive transfer of literacy skills between languages that resulted (Ballinger, 2013; Lyster, Collins, \& Ballinger, 2009; Lyster, Quiroga, \& Ballinger, 2013; Moore \& Sabatier, 2014). Coupled with findings from related FSL research showing that students' reading-related abilities and writing abilities impact each other within the same language and across languages (Savage, Kozakewich, Genesee, Erdos, \& Haigh, 2017), these interventions warrant consideration of the potential for students to develop strong biliteracy skills in the FSL school context, particularly given additional studies showing that FSL students draw from their plurilingual repertoires when reading and writing in French (e.g., Bournot-Trites \& Séror, 2003; Chung, Chen, \& Deacon, 2017; Swain \& Lapkin, 2000).

\section{French Language Form (FLF)}

Articles relating to FLF typically focused on four topics - corrective feedback, focus on form instruction, grammar instruction, or metalinguistic ability. ${ }^{2}$ Almost $80 \%$ of FLF studies were conducted in the FI context. In general, findings suggest that FSL development is positively influenced by corrective feedback, explicit instruction in grammar, and the metalinguistic advantages conferred by a good working knowledge of (or "proficiency in") more than one language.

With regard to corrective feedback, as FSL learners and teachers negotiate for meaning, Lyster (2002) emphasized that numerous opportunities arise to focus on form within the context of teaching subject matter or language arts in FI contexts. Certain types of feedback, called "prompts," in which teachers "push" students to clarify, repeat, provide metalinguistic clues, or elicit correct forms, have been shown to be effective in prompting learner uptake of new language-related information (Lyster, 2004). Moreover, focus on form instruction that is integrated across content areas in FI has been shown to spark progress in French language development, as do form-focused lessons through French across language arts lessons in both L1 and L2. For example, targeted form-focused instruction on certain noun endings that predict grammatical gender was shown to improve immersion students' command of gender marking in French nouns (e.g., Lyster, 2004).

Not surprisingly, French language learners' speech and writing are influenced by their home language, ${ }^{3}$ and several studies have explored the role of grammar instruction in improving these productive language skills in both FI and CF settings. Tipurita and Jean (2014) showed that early FI students benefited from explicit instruction in the gender of noun endings, assigning gender with greater accuracy to known and not-yet-encountered nouns (tested in speaking) after explicit teaching. Lyster (2004) found that prompts were helpful in the same area in Grade 5 FI writing. Jean (2005) also reported that Grade $10 \mathrm{CF}$ students were better able to produce the conditional form of the verb regardless of whether the form was taught in isolated grammar lessons or in meaningful contexts.

While young bilingual learners are known to have enhanced metalinguistic ability (e.g., Genesee, 1987), researchers have examined specific aspects of the metalinguistic advantage in FSL in particular. Examples include Lyster et al. (2013), who documented gains in derivational morphology (understanding the productive power of affixes: $j e$ tremble, tremblement de terre; agréable, désagréable $)^{4}$ and D'Angelo and Chen (2017) 
who found that scores on morphological awareness distinguished between poor and good "comprehenders." Jared, Cormier, Levy, and Wade-Woolley (2013) used a test of pseudowords to demonstrate that early FI students who develop early print knowledge in two languages also develop the ability to discriminate between orthographic patterns of English and French. While similar advantages of early bilingual education have been documented in the literature of the last century (e.g, Genesee, 1987), the articles included in our database extend earlier findings by focusing more narrowly on specific topics such as orthography and morphology in the FSL context in particular.

Finally, some studies take a broader perspective, focusing on aspects of FLF that students themselves "notice." For example, Lapkin, Swain, and Smith (2002) reformulated French texts written by Grade 8 FI participants. Confronted with their own texts that had been re-written "correctly," students were found to accept or reject changes that were made by the reformulator and cling to their own "rules." Tocalli-Beller and Swain (2005) found that such opportunities to compare these kinds of written texts and discuss differences between the two texts provided learners with the chance to reflect on their own language use.

\section{French Language Instruction (FLI)}

Among studies on FLI, the majority documented the specific practices of CF (44\%) and FI (49\%) teachers across a variety of pedagogical areas, including their use of technology, form-focused instruction, literacy-related teaching, inclusionary strategies, and mandated method implementation. In general, while findings offer useful descriptions of pedagogical practices in these contexts, they also distinguish between potential impacts of FLI, focusing predominantly on documenting change in students' French proficiency after experiencing specific FLI.

Documenting teacher practices in K-12 FSL over the years has offered readers insights into how French has been taught in CF and FI classrooms. For example, observations by Simard and Jean (2011) showed that grammar-oriented interventions are a dominant part of FSL teaching when compared to English as a second language (ESL) teaching in the Canadian context (in this case, Quebec). Precise ways in which both CF and FI teachers can capitalize on students' existing language knowledge in order to promote transfer between languages have also been described in detail (Arnott \& Mady, 2013; Cammarata \& Haley, 2017; Thomas \& Mady, 2014; Vandergrift, 2006). Researchers have used these findings to make suggestions about what is indeed pedagogically possible (or not) in the K-12 FSL context. Vandergrift (2006) highlighted the potential for formative L2 listening practice to help FSL students positively transfer inferencing strategies acquired in their L1 and further develop metacognitive knowledge about listening. Arnett's (2010) description of strategies used by a Grade 8 CF teacher showcased how practices aimed at maximizing the inclusion of students with learning exceptionalities could be used in this context. Research on technology-related practices has also yielded examples of possibilities and challenges related to their utility for teaching FSL: although Pellerin (2013) found that teachers' use of digital technologies in early FI facilitated their use of inclusive instructional strategies, the teacher participant in Taylor (2015) faced a variety of obstacles when trying to implement the technology component of a plurilingually-inspired project in their secondary FI context. 
It is worth noting that almost one-third of the studies on FLI analyzed the impact of observed FSL teacher practices on the student experience. The majority of these studies viewed the student experience in terms of their developing proficiency in French, while only a few included student perspectives on the instruction they were receiving. With respect to the latter, improved student attitudes toward French and their developing skill sets were reported following observations of an increase in time spent in French (Peters, MacFarlane, \& Wesche, 2004) and the use of strategies targeting reluctant French readers (Capina \& Bryan, 2017). Student participants in Jean and Simard (2011) also reported that grammar instruction in FSL was necessary and effective, but not fun.

With regard to developing French proficiency specifically, the majority of interventions studied since 2000 reported a subsequent improvement in students' French skills. For example, improvement was reported following grammar-oriented interventions that included focus-on-form activities paired with teacher feedback (Lyster, 2004) and explicit teaching of French gender (Tipurita \& Jean, 2014). In FI, studies have shown that students' writing improved following science teaching with a literacy-oriented focus (Cormier \& Turnbull, 2009), systematic instruction on opinionated essay writing (Le Bouthillier \& Dicks, 2013), or process writing (Kristmanson, Dicks, Le Bouthillier, \& Bourgoin, 2008). In contrast, Jean (2005) found that students were equally effective at using the conditional verb tense regardless of whether explicit teaching was linked to a meaningful context or not. Studies examining whether the use of a particular method used for FSL (i.e., the Accelerative Integrated Method [AIM] $)^{5}$ improved student performance also showed mixed results, with some studies showing superior oral skills for the AIM group (Bourdages \& Vignola, 2009, 2014) and another showing no statistical differences in the performance of AIM and non-AIM students (Lapkin et al., 2009).

Several studies were more comprehensive in their focus on both improved language learning and student engagement following a particular FLI intervention. For example, Rovers (2013) found that incorporating arts-based teaching in the Grade 9 CF classroom facilitated the development of students' oral and writing skills in French, while also enhancing their self-esteem, pride, and willingness to communicate in French. A biliteracy project implemented in the elementary FI classroom, where the French and English teachers both read different chapters of French and English versions of the same novel, was also shown to have a positive impact on students' morphological awareness (Lyster et al., 2013) and on their experiences and learning during peer collaboration (Ballinger, 2013).

Setting aside the impact of pedagogy on student learning, a smaller proportion of the studies documenting FSL teacher practices included a complementary analysis of teacher perspectives on their FSL pedagogy, which offered additional explanations for what the researchers had observed. For example, interviews revealed that CF teachers specifically plan for transfer (Thomas \& Mady, 2014) and that collaboration and coplanning are key to implementing literacy-based practices in this context (Arnott \& Mady, 2013). Other researchers used interviews to conclude that teacher beliefs had a major influence on the FSL teacher practices that were observed (e.g., Arnett, 2010; Arnott, 2011).

Some studies have focused exclusively on documenting teacher perspectives without observing teacher practices; these perspectives have provided insight into the teacher beliefs underpinning French language instruction. For example, research has detailed what FSL teachers think about technology (Murphy, 2002); the CEFR (Faez, Taylor, Majhanovich, Brown, \& Smith, 2011); inclusion of English language learners 
(ELLs) in FSL (Mady, 2012a); and grammar instruction (Jean \& Simard, 2011). Other studies have included teacher perspectives as part of a broader analysis of the responsibilities of different FSL stakeholders when it comes to French language instruction (Arnott, 2015; Milley \& Arnott, 2016).

\section{Student Background (SB)}

Studies in FSL examining SB considered such characteristics as gender, allophones, citizenship, immigration, and indigeneity. Over half of the studies coded as SB were set in an FI context (54\%) and just over one-third in CF contexts (36\%). In general, findings suggest that different facets of SB impact FSL students' motivation and their ability to perform in or access FSL programs. Studies on SB also reveal systemic barriers that can influence students' FSL experience.

Regarding students' FSL learning experiences linking to their gender, Kissau (2008) reported that boys are less intrinsically motivated to study French than girls and that boys are perceived to receive less encouragement than girls in FSL classrooms (Kissau, 2007). During interviews exploring the gender differences in motivation to study French, boys confirmed that they perceive French as a female domain (Kissau, 2006).

The increasing presence of allophones (i.e., those who speak languages other than French and English at home [Statistics Canada, 2016; Swain \& Lapkin, 2005]) in FSL classrooms is associated with growing interest in their experiences and engagement in FSL programs. For example, Makropoulos (2010) investigated allophone student engagement in a secondary FI school and identified factors such as language, class, culture, and race as influencing attitudes towards learning FSL. In interviews, students cited family background, interest in learning and using French inside and outside of school, learning styles, grades, and educational experiences as playing a role in shaping their attitude towards FSL. A detailed policy analysis by Mady and Turnbull (2010) also revealed that provincial policies create obstacles for allophones to access FSL and learning both official languages. Despite this trend, Mady (2010) found that allophones are more motivated to study FSL than their monolingual English-speaking Canadian-born peers. In addition, immigrant allophones have been shown to outperform their Canadian-born monolingual and multilingual peers in CF (Mady, 2007) and in FI (Mady, 2015b, 2015c), suggesting they possess higher integrative and instrumental motivation and willingness to speak French. Given that the "reasons for [participating Canadian immigrants'] successful acquisition are not yet determined" (Mady, 2015a), this body of research has significant implications for the field of FSL education, calling into question the assumption that allophones cannot succeed in FSL.

In line with these findings, recent studies reveal that educators' attitudes toward allophones are mostly positive regarding the inclusion of allophones in FSL classrooms (Mady, 2012a; Mady, Arnett, \& Muilenburg, 2017), but that some teachers continue to express the belief that FI in particular may not be suitable for allophones (Arnett \& Mady, 2017; Bourgoin, 2016). Concerns mainly emerged if allophones were in the early stages of learning English (and thus commonly categorized as ELLs). In response, researchers suggested that initial teacher education programs need to provide more information on how to make FSL classrooms inclusive and accessible (Arnett \& Mady, 2017), particularly given that FSL teacher candidates report not being prepared enough when it comes to teaching ELLs (Mady \& Arnett, 2015). For multilingual immigrant parents, English and 
French are perceived as valuable official languages in Canada; in particular, they view FI and multilingualism as advantageous for their children (Dagenais \& Berron, 2001). However, given that FI teachers are less likely to practice inclusion than CF teachers (Mady, 2013), immigrant students may not yet be able to access FI programs easily, despite their parents' wishes.

A related priority in other FSL research has been the investigation of FSL student citizenship and linguistic abilities in languages other than English. Learning an additional language involves developing literacy practices that are found to be key in constructing ideas of citizenship among students in FI. For instance, Sabatier, Moore, and Dagenais (2013) invited children in their study to explore the linguistic landscape in which they live and how they shaped their developing identity as Canadian citizens. Similar work, examining the relationship between multiliteracies and conceptualization of Canadian citizenship, has been conducted with FSL teacher candidates (Byrd Clark, 2008). Moore (2010) found that multilingual children demonstrated they are capable of creatively using the various linguistic repertoires at their disposal to mediate their experience with migration and mobility, and negotiate new identities. In fact, when plurilingual literacy practices are valued in school, they can lead to scholastic success and to forming citizenship without loss of heritage (Dagenais \& Moore, 2008).

In 2008, Dagenais found that multilingual immigrant students who came to schools that valued their linguistic repertoires were able to develop positive identities, revealing the importance of discursively constructed perceptions for understanding the reality of immigrant student experiences in FSL. Recent work by Waterhouse and Arnott (2016) highlighted how "taken-for-granted" representations of immigrant experiences in FSL (for instance, immigrant status being a challenge to overcome or an advantage to exploit) do not allow for the affective potential of an immigrant life to move beyond such representations. Mady (2012b) found that immigrant participants came to Canada with the idea that official bilingualism was a part of Canadian identity, despite their perceptions about Canadian-ness changing after arriving in Canada, participants and their families continued to value and pursue English-French bilingualism as a means to improve job-seeking opportunities.

With regard to learning FSL in an Indigenous schooling context, experimental research examining the effect of explicit vocabulary instruction found that Indigenous learners in the experimental group significantly outperformed those in the control group (Lavoie, 2015). The fact that this is the only study to date that investigates the learning experiences of Indigenous learners suggests more work is needed to understand FSL learning in Indigenous schooling contexts.

\section{Conclusion}

In accordance with the objective of a research synthesis (Norris \& Ortega, 2006), the remainder of this article aims to summarize "what we know" (see subheading) about K12 FSL education based on the findings presented above, and explore what we do not know about these and other related issues, including some speculation as to why such gaps may persist (all presented under the subheading “what remains to be discovered?"). In this vein, relevant directions for future research in FSL K-12 education contexts are also suggested. 


\section{What We Know}

Broadly speaking, the majority of what we know about K-12 FSL education from existing research published since 2000 is concentrated in four specific areas (literacy, FLF, FLI and SB) and in one specific FSL program (i.e., FI). With regard to FLI, research offers a glimpse into pedagogical practices in the delivery of CF and FI programs. Investigation of the impact of these practices has focused primarily on students' developing language skills, with a secondary focus on student and teacher perspectives on the instructional practices in question. Regarding literacy, it is clear that the development of traditional and "new" literacy skills has caught the attention of researchers in the field of K-12 FSL education; however, this interest is almost exclusively concentrated in the FI context. Much has been discovered about the potential for reconceptualizing the understanding of literacy skills to include biliteracy development and cross-linguistic transfer, particularly for the purposes of responding to the needs of students who struggle in FI (Genesee, 2007).

In particular, discussion of cross-linguistic transfer and translanguaging (García, 2009; Lau, Juby-Smith, \& Desbiens, 2017) has recently (re)entered the field of language education in Canada (e.g., Lau, 2019; Starks, 2018; Stille, Bethke, Bradley-Brown,

Giberson, \& Hall, 2016). Although the research has evolved from questioning the presence of the L1 (i.e., English) in the classroom (Turnbull, 2001) to accepting that the L1 (in many cases English, which is also the majority language in Canada) can make significant metacognitive, phonological, and sociolinguistic contributions to student learning (Cummins, 2014), debates continue as to its use as a mediational tool for learning in the FSL classroom (Ballinger, Lyster, Sterzuk, \& Genesee, 2017). In this vein, language status remains a key variable in determining successful student learning and identity development in French.

Researchers have also persisted in exploring effective ways to teach FLF in intervention studies. Synthesized findings showed that corrective feedback, focus on form, explicit instruction in grammar, and proficiency in more than one language all led to improved French language proficiency. The issue of SB in both CF and FI contexts is of recent interest to the field, revealing the challenge of overcoming assumptions about student performance based on linguistic background or immigrant status. This research has also highlighted the importance of considering learners' developing identities and evolving sense of citizenship as they add French to their linguistic repertoires. Generally speaking, FSL research is still in the early stages of grappling with the implications of teaching French to heterogeneous student populations; however, there have been ongoing discussions in recent years to incorporate an intercultural dimension to FSL teaching (e.g., Kristmanson \& Dicks, 2014; Vanthuyne \& Byrd Clark, 2015).

A significant number of studies conducted since 2000 aimed to isolate specific instructional strategies, language forms, or attributes of a student's background as bounded influences on FSL students' linguistic development and engagement. Although these findings provide much-needed insight into how such segmented aspects of K-12 FSL education interact in both positive and negative ways, they also demonstrate the complexity of researching whether one single method, strategy, or attribute can predict student success in FSL. This synthesis suggests that the impact of FLI is being considered more comprehensively: instead of student diversity being treated as a confounding research variable, it is being viewed as an asset in FSL education contexts. Looking across time, it appears that FSL researchers have also begun to move beyond examining student outcomes 
using quasi-experimental designs toward showcasing the valuable insights that can be gained by gauging stakeholder perspectives on their FSL teaching and learning experiences.

\section{What Remains to Be Discovered?}

In general, the body of K-12 FSL research published since 2000 does not tell much about what is happening in FSL programs other than FI-for example, CF, EF, IF. Specifically, little is known about how issues of literacy and FLF are taken up outside of the FI context. For instance, despite literacy being the most frequently occurring key word, only five studies addressed this topic in the CF context, and only one respectively, in EF and IF programs. One cannot decisively say whether this is due to a purposeful avoidance of studying contexts outside of FI or merely a keen interest in FI. Certainly, the widespread focus on how students acquire literacy and numeracy skills in terms of the general curriculum could explain this empirical preoccupation with FI, with its grounding in learning content through an additional language. As well, statistics show that more and more students are enrolling in FI, ${ }^{6}$ a trend that would justify a concentrated research focus in this context. Other programs, like $\mathrm{CF}$, have suffered chronic undervaluing and marginalization in Canadian FSL education (Lapkin et al., 2009), which could feasibly explain the lack of empirical interest in the program or its outcomes since 2000. Many of the existing findings could logically apply to learning French in CF, EF, or IF (e.g., potential for biliteracy and cross-linguistic transfer), but the lack of research in this regard does not reflect enrolment trends showing that the majority of Canadian students do not learn FSL via FI. At the very least, these findings clearly demonstrate the need for more empirical inquiry into other FSL programs.

It is worth noting that less-frequent topics also intersected with the top four key words presented (e.g., technology, assessment, CEFR, exceptionalities, inclusion, identity), suggesting there are some additional areas of interest in the research. In the case of everevolving aspects of FSL education, for example technology, it can only be noted that this topic has become more embedded in the research design, rather than being investigated as a pedagogical tool in and of itself as it was at the start of the century (see Turnbull \& Lawrence, 2001, 2003). More research is needed to understand how the shift toward Web 2.0 technologies (that allow for interactivity on the Web) have altered teachers' FLI. Other topics, such as inclusion and exceptionalities, are new to the field of FSL and continue to be developed and debated through research and advocacy (e.g., Arnett \& Mady, 2010).

Noticeably absent from the FSL research agenda to date is the perspective of First Nations, Métis, and Inuit (FNMI) teachers and students in the field of French as an additional language. If researchers were to investigate styles of learning and language acquisition of French, English, and ancestral Indigenous languages, it would be a way to supplement research on plurilingualism in the Canadian context. Conducting research with FNMI teachers in on-reserve or off-reserve community schools could also provide insight into new pedagogical approaches (e.g., holistic, place-based, culturallyresponsive/culturally-safe) that augment and sustain multiple linguistic repertoires in Canadian schools. Working with FNMI communities in this way could prompt FSL researchers to consider alternative, decolonized methodologies (Smith, 2013) and diverse philosophies of learning, being (ontologies), and knowing (epistemologies) in the language classroom. 
Correspondence should be addressed to Stephanie Arnott.

Email: sarnott@uottawa.ca

\section{Notes}

${ }^{1}$ For definitions of these program terms, see for example: Canadian Parents for French. (2017). The state of French second language education in Canada 2017. Ottawa, Canada: Canadian Parents for French.

${ }^{2}$ For the purposes of this article, metalinguistics also subsumes other key words we identified in the FLF group. These include morphological awareness, orthographic processing, reciprocal learning, and reformulation.

${ }^{3}$ Francophones in minority settings also share some non-standard features in using French: Nadasdi (2001) found that failure to mark $3^{\text {rd }}$ person plural in verbs (e.g., ils doivent) was similar for FI and Francophone learners with restricted French use.

${ }^{4}$ Translations of these words are: I am shaking/trembling; earthquake; agreeable; disagreeable.

${ }^{5} \mathrm{AIM}$ is a teaching method that combines exclusive target language use with gestures, choral activity, and drama, among other strategies (see AIM Language Learning, 2018, for more information).

${ }^{6}$ For enrolment statistics, see https://cpf.ca/en/files/Enrolement-Stats-2018-web.pdf

\section{References}

AIM Language Learning. (2018). Retrieved from www.aimlanguagelearning.com

Arnett, K. (2010). Scaffolding inclusion in a grade 8 core French classroom: An exploratory case study. Canadian Modern Language Review, 66(4), 557-582.

Arnett, K., \& Mady, C. (2010). A critically conscious examination of special education within FSL and its relevance to FSL teacher education programs. Canadian Journal of Applied Linguistics, 13(1), 19-36.

Arnett, K., \& Mady, C. (2017). Core or immersion? Canadian French-second-language teacher candidates' perceptions and experiences of the best and worst program options for students with learning difficulties and for English language learners. Exceptionality Education International, 27(1), 17-37.

Arnott, S. (in press). Giving voice to our core French students: Implications for attrition and the discourse on the benefits of learning FSL in Ontario. McGill Journal of Education.

Arnott, S. (2011). Exploring the dynamic relationship between the Accelerative Integrated Method (AIM) and the core French teachers who use it: Why agency and experience matter. Canadian Journal of Applied Linguistics, 14(2), 156-176.

Arnott, S. (2015). Second language education and micro-policy implementation in Canada: The meaning of pedagogical change. Language Teaching Research, 21(2), 258-284. 
Arnott, S., \& Mady, C. (2013). Obstacles and opportunities for literacy teaching: A case study of primary core French classrooms in Ontario. Language and Literacy, 15(2), 101-127.

Ballinger, S. (2013). Towards a cross-linguistic pedagogy: Biliteracy and reciprocal learning strategies in French immersion. Journal of Immersion and Content-Based Language Education, 1(1), 131-148.

Ballinger, S., Lyster, R., Sterzuk, A., \& Genesee, F. (2017). Context-appropriate crosslinguistic pedagogy: Considering the role of language status in immersion education. Journal of Immersion and Content-Based Language Education, 5(1), 3057.

Barbour, R. S. (1998). Mixing qualitative methods: Quality assurance or qualitative quagmire? Qualitative health research, 8(3), 352-361.

Bérubé, D., \& Marinova-Todd, S. H. (2014). The effect of sociolinguistic factors and English language proficiency on the development of French as a third language. International Journal of Bilingual Education and Bilingualism, 17(4), 465-483.

Bourdages, J. S., \& Vignola, M.-J. (2009). Évaluation des habiletés de communication orale chez des élèves de 1'élémentaire utilisant AIM. Canadian Modern Language Review, 65(5), 731-755.

Bourdages, J. S., \& Vignola, M.-J. (2014). Profil lexical à l'oral d'élèves de français langue seconde exposés à l'approche gestuelle AIM. Revue canadienne de linguistique appliquée, 17(1), 78-100.

Bourgoin, R. (2014). The predictive effects of L1 and L2 early literacy indicators on reading in French immersion. Canadian Modern Language Review, 70(3), 355-380.

Bourgoin, R. (2016). French immersion "So why would you do something like that to a child?": Issues of advocacy, accessibility, and inclusion. International Journal of Bias, Identity and Diversities in Education, 1(1), 42-58.

Bournot-Trites, M., Lee, E., \& Séror, J. (2003). Tutorat par les pairs en lecture : une collaboration parents-école en milieu d'immersion française. Revue des sciences de l'éducation, 29(1), 195-210.

Bournot-Trites, M., \& Séror, J. (2003). Students' and teachers' perceptions about strategies which promote proficiency in second language writing. Canadian Journal of Applied Linguistics, 6(2), 129-157.

Byrd Clark, J. (2008). So why do you want to teach French? Representations of multilingualism and language investment through a reflexive critical sociolinguistic ethnography. Ethnography and Education, 3(1), 1-16.

Cammarata, L., \& Haley, C. (2017). Integrated content, language, and literacy instruction in a Canadian French immersion context: A professional development journey. International Journal of Bilingual Education and Bilingualism, 21(3), 1-17.

Canadian Parents for French. (2017). The state of French second language education in Canada 2017. Ottawa, Canada: Canadian Parents for French. Retrieved from https://cpf.ca/en/files/State-of-FSL-Education-Report-Final-Web.pdf

Canadian Standing Senate Committee on Official Languages. (2015). Aiming higher: Increasing bilingualism in our Canadian youth. Ottawa, Canada. Retrieved from www.senate-senat.ca/ollo.asp

Capina, A. B., \& Bryan, G. (2017). Engaging reluctant readers in a French immersion classroom. Current Issues in Education, 20(1), 332-348. 
Carr, W. (2009). Intensive French in British Columbia: Student and parent perspectives and English as additional language (EAL) student performance. Canadian Modern Language Review, 65(5), 787-815.

Chung, S. C., Chen, X., \& Deacon, S. H. (2017). The relation between orthographic processing and spelling in grade 1 French immersion children. Journal of Research in Reading, 41(2), 290-311.

Chung, S. C., Koh, P. W., Deacon, S. H., \& Chen, X. (2017). Learning to read in English and French: Emergent readers in French immersion. Topics in Language Disorders, 37(2), 136-153.

Collins, J., Stead, S., \& Woolfrey, S. (2004). Rethinking teaching strategies for intensive French. Canadian Modern Language Review, 60(3), 355-372.

Cooper, H. M., Patall, E. A., \& Lindsay, J. J. (2013). Research synthesis and meta-analysis. In L. Bickman \& D. J. Rog (Eds.), The SAGE handbook of applied social research methods (pp. 344-370). Thousand Oaks, CA: Sage.

Cooper, L., \& Hedges, H. (2009). Research synthesis as a scientific process. In H. Cooper, L. V. Hedges, \& J. C. Valentine (Eds.), The handbook of research synthesis and meta-analysis (pp. 3-16). New York, NY: Russell Sage Foundation.

Cormier, M., \& Turnbull, M. (2009). Une approche littératiée : apprendre les sciences et la langue en immersion tardive. La Revue canadienne des langues vivantes, 65(5), 817-840.

Cummins, J. (2014). Rethinking pedagogical assumptions in Canadian French immersion programs. Journal of Immersion and Content-Based Language Education, 2(1), 3 22.

D’Angelo, N., \& Chen, X. (2017). Language profiles of poor comprehenders in English and French. Journal of Research in Reading, 40(2), 153-168.

Dagenais, D. (2008). La prise en compte du plurilinguisme d'enfants issus de familles immigrantes en contexte scolaire : une analyse de cas. Revue des sciences de l'éducation, 34(2), 351-375.

Dagenais, D., \& Berron, C. (2001). Promoting multilingualism through French immersion and language maintenance in three immigrant families. Language, Culture and Curriculum, 14(2), 142-155.

Dagenais, D., \& Moore, D. (2008). Représentations des littératies plurilingues, de l'immersion en français et des dynamiques identitaires chez des parents chinois. $L a$ Revue canadienne des langues vivantes, 65(1), 11-31.

Desgrosseilliers, P. (2012). Étude des représentations du bilinguisme et du français langue seconde chez des apprenants en Colombie Britannique (Doctoral dissertation). Retrieved from http://summit.sfu.ca/item/12300

Desgrosseilliers, P. (2017). BC students speak up about core French. In Canadian Parents for French, The state of French Second Language in Canada, 2017 (pp. 12-15). Ottawa, Canada: Canadian Parents for French.

Dixon-Woods, M., Kirk, M. D., Agarwal, M. S., Annandale, E., Arthur, T., Harvey, J., . . . Smith, L. (2005). Vulnerable groups and access to health care: A critical interpretive review. Report for the National Co-ordinating Centre for NHS Service Delivery and Organisation $R \& D$ (NCCSDO). Retrieved from http://www.netscc.ac.uk/hsdr/files/project/SDO_FR_08-1210-025_V01.pdf

Duff, P., Norris, J. M., \& Ortega, L. (2007). The future of research synthesis in applied linguistics: Beyond art or science. TESOL Quarterly, 41(4), 805-815. 
Faez, F., Taylor, S., Majhanovich, S., Brown, P., \& Smith, M. (2011). Teachers' reactions to CEFR's task-based approach for FSL classrooms. Synergies Europe, 6, 109-120.

Flemming, K. (2010). Synthesis of quantitative and qualitative research: An example using critical interpretive synthesis. Journal of Advanced Nursing, 66(1), 201-217.

García, O. (2009). Bilingual education in the $21^{\text {st }}$ century: A global perspective. Oxford, United Kingdom: Blackwell.

Genesee, F. (1987). Learning through two languages: Studies of immersion and bilingual education. Cambridge, MA: Newbury House.

Genesee, F. (2007). Immersion française et élèves à risques : revue des données de recherche. The Canadian Modern Language Review, 63(5), 689-726.

Germain, C., Netten, J., \& Séguin, S. (2004). L'évaluation de la production écrite en français intensif : critères et résultats. La Revue canadienne des langues vivantes, 60(3), 333-353.

Glaser, B. G., \& Strauss, A. L. (1967). The discovery of grounded theory: Strategies for qualitative theory. New York, NY: Aldine Publishing.

Hipfner-Boucher, K., Lam, K., \& Chen, X. (2015). The contribution of narrative morphosyntactic quality to reading comprehension in French immersion students. Applied Psycholinguistics, 36(6), 1375-1391.

Jared, D., Cormier, P., Levy, B. A., \& Wade-Woolley, L. (2010). Early predictors of biliteracy development in children in French immersion: A 4-year longitudinal study. Journal of Educational Psychology, 103(1), 119.

Jared, D., Cormier, P., Levy, B. A., \& Wade-Woolley, L. (2013). Discrimination of English and French orthographic patterns by biliterate children. Journal of Experimental Child Psychology, 114(4), 469-488.

Jasińska, K. K., \& Petitto, L. A. (2017). Age of bilingual exposure is related to the contribution of phonological and semantic knowledge to successful reading development. Child Development, 89(1), 310-331.

Jean, G. (2005). Intégration de la grammaire dans l'enseignement des langues secondes : le cas des exercices grammaticaux. La Revue canadienne des langues vivantes, 61(4), 519-542.

Jean, G., \& Simard, D. (2011). Grammar teaching and learning in L2: Necessary, but boring? Foreign Language Annals, 44(3), 467-494.

Kissau, S. (2006). Gender differences in motivation to learn French. Canadian Modern Language Review, 62(3), 401-422.

Kissau, S. (2007). Is what's good for the goose good for the gander? The case of male and female encouragement to study French. Foreign Language Annals, 40(3), 419-432.

Kissau, S. (2008). "Crêpes on Friday": Examining gender differences in extrinsic motivation in the French as a second language classroom. Issues in Applied Linguistics, 16(1), 31-47.

Knouzi, I., \& Mady, C. (2017). Indicators of an "immigrant advantage" in the writing of L3 French learners. Canadian Modern Language Review, 73(3), 368-392.

Kristmanson, P., \& Dicks, J. (2014). Looking in the one-way mirror: Reflections on the changing face(s) of immersion in North America and beyond. Journal of Immersion and Content-Based Language Education, 2(2), 273-287.

Kristmanson, P., Dicks, J., Le Bouthillier, J., \& Bourgoin, R. (2008). L'écriture en immersion française : les meilleures pratiques et le rôle d'une communauté 
professionnelle d'apprentissage. Revue canadienne de linguistique appliquée, 11(1), 41-61.

Kruk, R. S., \& Reynolds, K. A. (2012). French immersion experience and reading skill development in at-risk readers. Journal of Child Language, 39(03), 580-610.

Lapkin, S., MacFarlane, A., \& Vandergrift, L. (2006). Teaching French in Canada: FSL teachers' perspectives. Ottawa, Canada: Canadian Teachers' Federation. Retrieved from https://www.caslt.org/files/pd/resources/research/2006-teaching-fsl-in-canadaen.pdf

Lapkin, S., Mady, C., \& Arnott, S. (2009). Research perspectives on core French: A literature review. Canadian Journal of Applied Linguistics, 12(2), 6-30.

Lapkin, S., Swain, M., \& Smith, M. (2002). Reformulation and the learning of French pronominal verbs in a Canadian French immersion context. Modern Language Journal, 86(4), 485-507.

Lau, S. M. C. (2019). Convergences and alignments between translanguaging and critical literacies work in bilingual classrooms. Translation and Translanguaging in Multilingual Contexts, 5(1), 67-85.

Lau, S. M. C., Juby-Smith, B., \& Desbiens, I. (2017). Translanguaging for transgressive praxis: Promoting critical literacy in a multiage bilingual classroom. Critical Inquiry in Language Studies, 14(1), 99-127.

Lavoie, C. (2015). Trois stratégies efficaces pour enseigner le vocabulaire : une expérience en contexte scolaire innu. Revue canadienne de linguistique appliquée, 18(1), 1-20.

Lazaruk, W. (2007). Linguistic, academic, and cognitive benefits of French immersion. Canadian Modern Language Review, 63(5), 605-627.

Le Bouthillier, J. (2015). Writing progress and processes of grade 7 at-risk French immersion students. International Journal of Technology and Inclusive Education, 5(1), 690-697.

Le Bouthillier, J., \& Dicks, J. (2013). L'emploi d'un modèle d'enseignement systématique d'écriture: une étude de cas en $7^{\mathrm{e}}$ année de l'immersion précoce. La Revue canadienne des langues vivantes, 69(3), 298-323.

Lyster, R. (2002). Negotiation in immersion teacher-student interaction. International Journal of Educational Research, 37(3), 237-253.

Lyster, R. (2004). Differential effects of prompts and recasts in form-focused instruction. Studies in Second Language Acquisition, 26(3), 399-432.

Lyster, R., Collins, L., \& Ballinger, S. (2009). Linking languages through a bilingual readaloud project. Language Awareness, 18(3-4), 366-383.

Lyster, R., Quiroga, J., \& Ballinger, S. (2013). The effects of biliteracy instruction on morphological awareness. Journal of Immersion and Content-Based Language Education, 1(2), 169-197.

Mady, C. (2007). Allophone students in French second-official-language programs: A literature review. Canadian Modern Language Review, 63(5), 727-760.

Mady, C. (2010). Motivation to study core French: Comparing recent immigrants and Canadian-born secondary school students. Canadian Journal of Education, 33(3), 564-587.

Mady, C. (2012a). Inclusion of English language learners in French as a second official language classes: Teacher knowledge and beliefs. International Journal of Multilingualism, 9(1), 1-14. 
Mady, C. (2012b). Voices of immigrant adults: Perspectives and experiences with French as a second official language in "English-dominant" Canada. Journal of Modern Languages and International Studies, 1(1), 35-51.

Mady, C. (2013). Moving towards inclusive French as a second official language education in Canada. International Journal of Inclusive Education, 17(1), 47-59.

Mady, C. (2015a). The bilingual advantage for immigrant students in French immersion in Canada: Linking advantages to contextual variables. International Journal of Bilingual Education and Bilingualism, 20(3), 235-251.

Mady, C. (2015b). Examining immigrants' English and French proficiency in French immersion. Journal of Immersion and Content-Based Language Education, 3(2), 268-284.

Mady, C. (2015c). Immigrants outperform Canadian-born groups in French immersion: Examining factors that influence their achievement. International Journal of Multilingualism, 12(3), 298-311.

Mady, C., \& Arnett, K. (2015). French as a second language teacher candidates' conceptions of allophone students and students with learning difficulties. Canadian Journal of Applied Linguistics, 18(2), 78-95.

Mady, C., Arnett, K., \& Muilenburg, L. Y. (2017). French second-language teacher candidates' positions towards allophone students and implications for inclusion. International Journal of Inclusive Education, 21(1), 103-116.

Mady, C., \& Turnbull, M. (2010). Learning French as a second official language: Reserved for Anglophones? Canadian Journal of Educational Administration and Policy, 99, $1-23$.

Makropoulos, J. (2010). Students' attitudes to the secondary French immersion curriculum in a Canadian context. Language, Culture and Curriculum, 23(1), 1-13.

Masson, M., Arnott, S., \& Lapkin, S. (2018). Teachers in K-12 FSL programs: What issues are top of mind in $21^{\text {st }}$ century research? Ottawa, Canada: Canadian Parents for French. Retrieved from https://cpf.ca/en/files/State-of-FSL-Education-ReportWeb.pdf

Milley, P., \& Arnott, S. (2016). The nature of principals' work and leadership in French as a second language learning in Ontario schools. Canadian Journal of Education, 39(1), 1-29.

Moore, D. (2010). Multilingual literacies and third script acquisition: Young Chinese children in French immersion in Vancouver, Canada. International Journal of Multilingualism, 7(4), 322-342.

Moore, D., \& Sabatier, C. (2014). Les approches plurielles et les livres plurilingues. De nouvelles ouvertures pour l'entrée dans l'écrit en milieu multilingue et multiculturel. Nouveaux c@hiers de la recherche en éducation, 17(2),32-65.

Murphy, E. (2002). New tools in an old trade: Teachers talk about use of the Internet in the teaching of French as a second or foreign language. Canadian Modern Language Review, 59(2), 215-235.

Nadasdi, T. (2001). Agreeing to disagree: Variable subject-verb agreement in immersion French. Canadian Journal of Applied Linguistics, 4(1-2), 87-101.

Norris, M., \& Ortega, L. (2006). Synthesizing research on language learning and teaching. Amsterdam, Netherlands: John Benjamins. 
Pellerin, M. (2013). E-inclusion in early French immersion classrooms: Using digital technologies to support inclusive practices that meet the needs of all learners. Canadian Journal of Education, 36(1), 44-70.

Peters, M., MacFarlane, A., \& Wesche, M. (2004). Le régime pédagogique du français intensif à Ottawa : le bain linguistique. La Revue canadienne des langues vivantes, 60(3), 373-391.

Priego, S., \& Liaw, M.-L. (2017). Understanding different levels of group functionality: Activity systems analysis of an intercultural telecollaborative multilingual digital storytelling project. Computer Assisted Language Learning, 30(5), 368-389.

Rovers, A. C. (2013). Teaching core French through the arts. Journal of Teaching and Learning, 9(1), 1-11.

Sabatier, C., Moore, D., \& Dagenais, D. (2013). Espaces urbains, compétences littératiées multimodales, identités citoyennes en immersion française au Canada. Glottopol, 21, 138-161.

Saindon, J., Landry, R., \& Boutouchent, F. (2011). Anglophones majoritaires et français langue seconde au Canada : effets complémentaires de la scolarisation et de l'environnement social. Revue canadienne de linguistique appliquée, 14(1), 64-85.

Savage, R., Kozakewich, M., Genesee, F., Erdos, C., \& Haigh, C. (2017). Predicting writing development in dual language instructional contexts: Exploring crosslinguistic relationships. Developmental Science, 20(1), 1-13.

Simard, D., \& Jean, G. (2011). An exploration of L2 teachers' use of pedagogical interventions devised to draw L2 learners' attention to form. Language Learning, 61(3), 759-785.

Smith, L. T. (2013). Decolonizing methodologies: Research and Indigenous peoples. Dunedin, New Zealand: University of Otago Press.

Starks, D. (2018). Translanguaging: A vital resource for First Nations Peoples. In G. Mazzaferro (Ed.), Translanguaging as everyday practice (pp. 107-124): Cham, Switzerland: Springer.

Statistics Canada. (2016). Immigration and ethnocultural diversity in Canada. Ottawa, Canada: Citizenship and Immigration Canada.

Stille, S. V. V., Bethke, R., Bradley-Brown, J., Giberson, J., \& Hall, G. (2016). Broadening educational practice to include translanguaging: An outcome of educator inquiry into multilingual students' learning needs. Canadian Modern Language Review, 72(4), 480-503.

Swain, M., \& Lapkin, S. (2000). Task-based second language learning: The uses of the first language. Language Teaching Research, 4(3), 251-274.

Swain, M., \& Lapkin, S. (2005). The evolving sociopolitical context of immersion education in Canada: Some implications for program development. International Journal of Applied Linguistics, 15(2), 169-186.

Taylor, S. K. (2015). Conformists \& mavericks: Introducing IT-enabled plurilingual pedagogy informed by the CEFR in high school French immersion. Intercultural Education, 26(6), 515-529.

Thomas, R., \& Mady, C. (2014). Teaching for transfer: Insights from theory and practices in primary-level French-second-language classrooms. McGill Journal of Education, 49(2), 399-416. 
Tipurita, M.-E., \& Jean, G. (2014). Enseignement explicite du genre des noms en français : expérimentation au primaire en classe d'immersion. La Revue canadienne des langues vivantes, 70(3), 279-302.

Tocalli-Beller, A., \& Swain, M. (2005). Reformulation: The cognitive conflict and L2 learning it generates. International Journal of Applied Linguistics, 15(1), 5-28.

Turnbull, M. (2001). There is a role for the L1 in second and foreign language teaching, but ... . The Canadian Modern Language Review, 57(4), 531-540.

Turnbull, M., \& Lawrence, G. (2001). Core French teachers and technology: Classroom application and belief systems. Ottawa, Canada: Canadian Association of Second Language Teachers (CASLT). Retrieved from https://www.caslt.org/files/pd/resources/research/2001-core-french-teachers-andtechnology-report.pdf

Turnbull, M., \& Lawrence, G. (2003). Core French teachers and technology: Classroom application and belief systems. Journal of Educational Thought, 37(3), 303-328.

Vandergrift, L. (2006). Second language listening: Listening ability or language proficiency? The Modern Language Journal, 90(1), 6-18.

Vanthuyne, A., \& Byrd Clark, J. (2015). Teaching for change \& diversity. In L. Thomas \& M. Hirschkorn (Eds.), Change and progress in Canadian teacher education: Research on recent innovations in teacher preparation in Canada (pp. 525-549). Ottawa, Canada: Canadian Association for Teacher Education.

Waterhouse, M., \& Arnott, S. (2016). Affective disruptions of the immigrant experience: Becomings in official language education research in Canada. International Multilingual Research Journal, 10(1), 121-136.

Wise, N., \& Chen, X. (2010). At-risk readers in French immersion: Early identification and early intervention. Canadian Journal of Applied Linguistics, 13(2), 128-149.

Wise, N., \& Chen, X. (2015). Early intervention for struggling readers in grade one French immersion. The Canadian Modern Language Review, 71(3), 288-306.

Wise, N., D’Angelo, N., \& Chen, X. (2016). A school-based phonological awareness intervention for struggling readers in early French immersion. Reading and Writing, 29(2), 183-205. 
Appendix A

Key Words Coding for Issues

\begin{tabular}{lc}
\hline Name & Articles coded \\
\hline Literacy & 47 \\
French language form & 39 \\
French language instruction & 37 \\
Student background & 30 \\
Professional development & 27 \\
Multilingualism & 25 \\
French language learning & 22 \\
Bilingualism & 20 \\
Motivation & 20 \\
Inclusion & 19 \\
Identity & 18 \\
Exceptionalities & 18 \\
Cross-linguistic transfer & 17 \\
Proficiency & 17 \\
Content-based learning & 16 \\
Collaborative dialogue & 15 \\
Ideologies & 15 \\
Assessment & 14 \\
Vocabulary & 13 \\
Oral communication & 12 \\
Language use & 12 \\
Linguistic variation & 11 \\
CEFR & 10 \\
Language policies & 10 \\
Technology & 9 \\
Multiculturalism & 9 \\
Plurilingualism & 9 \\
Language awareness & 6 \\
Family & 6 \\
Language portfolio & 5 \\
Affect & 5 \\
Learner autonomy & 3 \\
Physical space & 3 \\
Metacognition & 3 \\
Multimodality & 2 \\
Academic achievement & 2 \\
Enrollment & 2 \\
Rural education & 2 \\
Non-native teachers &
\end{tabular}


Leadership

Social justice

Teacher shortage

Interculturality

Study abroad

\section{1}

1

Mental imagery

1

1

1

1 